\title{
Acclimation of maximum quantum yield of PSII and photosynthetic pigments of Panax quinquefolius L. to understory light
}

\author{
Anick R. Fournier*, John T.A. Proctor**, Shahrokh Khanizadeh***, \\ André Gosselin* and Martine Dorais****,\# \\ *Horticultural Research Center, Envirotron Building, Laval University, Ste-Foy, Quebec, Canada, G1K 7P4 \\ **Department of Plant Agriculture, University of Guelph, Guelph, Ontario, Canada, NIG 2W1 \\ ***Agriculture and Agri-Food Canada, Horticultural Research Center, St-Jean-sur-Richelieu, Quebec, Canada, J3B 3E6 \\ ****Agriculture and Agri-Food Canada, Horticultural Research Center, Envirotron Building, \\ Laval University, Ste-Foy, Quebec, Canada, G1K 7P4
}

(Received November 24, 2008; Accepted December 20, 2008)

\begin{abstract}
Forest-grown American ginseng (Panax quinquefolius L.) is exposed to daily and seasonal light variations. Our goal was to determine the effect of understory light changes on the maximum quantum yield of photosystem II, expressed as $\mathrm{F}_{\mathrm{v}} / \mathrm{F}_{\mathrm{m}}$, and photosynthetic pigment composition of two-year-old plants. Understory light photon flux density and sunfleck durations were characterized using hemispherical canopy photography. Our results showed that understory light significantly affected the $\mathrm{F}_{\mathrm{v}} / \mathrm{F}_{\mathrm{m}}$ of American ginseng, especially during the initial development of the plants when light levels were the highest, averaging $28 \mathrm{~mol} \mathrm{~m}^{-2} \mathrm{~d}^{-1}$. Associated with low $\mathrm{F}_{\mathrm{v}} / \mathrm{F}_{\mathrm{m}}$ during its initial development, American ginseng had the lowest levels of epoxidation state of the xanthophyll cycle of the season, suggesting an active dissipation of excess light energy absorbed by the chlorophyll pigments. As photon flux density decreased after the deployment of the forest canopy to less than $10 \mathrm{~mol} \mathrm{~m}^{-2} \mathrm{~d}^{-1}$, chlorophyll a/b decreased suggesting a greater investment in light harvesting pigments to reaction centers in order to absorb the fleeting light energy.
\end{abstract}

Key words : American ginseng; Antheraxanthin; Chlorophyll fluorescence; Panax quinquefolius; Violaxanthin; Xanthophylls; Zeaxanthin

\begin{abstract}
Abbreviations
A, Antheraxanthin; Chl a, Chlorophyll a; Chl b, Chlorophyll b; Chl a+b, Pool size of chlorophyll a and b components; $\mathrm{Chl} \mathrm{a} / \mathrm{b}$, Chlorophyll a to $\mathrm{b}$ ratio; EPS epoxidation state of the xanthophyll cycle, $(\mathrm{V}+0.5 \mathrm{~A}) /(\mathrm{V}+\mathrm{A}+\mathrm{Z}) ; \mathrm{F}_{\mathrm{v}} / \mathrm{F}_{\mathrm{m}}$, Maximum quantum yield of photosystem II photochemistry; PFD, Photon flux density; PSII, Photosystem II; Total Car, Pool size of total carotenoid (V, A, Z, lutein, neoxanthin, $\beta$-carotene) components; V, Violaxanthin; $V+A+Z$, Pool size of xanthophyll cycle components, Z, Zeaxanthin.
\end{abstract}

\section{INTRODUCTION}

American ginseng (Panax quinquefolius L.) is a perennial shade plant endemic to the shady understory of broadleaf forests, ${ }^{1,2)}$ highly valued for its medicinal properties

\footnotetext{
\# To whom correspondence should be addressed.

(Tel) 418-656-2131; (Fax) 418-656-3515

(E-mail) doraisma@agr.gc.ca
}

generally attributed to the presence of ginsenosides. ${ }^{3,4)}$ Ginseng plants growing in North American conditions begin their foliar development in late spring (May) which coincides with the beginning of the development of the forest canopy leaves. Forest understories offer a heterogeneous light environment as the light levels not only vary seasonally due to the development of the forest canopy, but also daily due to the presence of sunflecks. Once the development of the forest canopy is complete from end of May to late June, ${ }^{2)}$ understory plants are generally exposed to moderate light intensities, although they remain exposed to sunflecks. Sunflecks can be sources of excessive light which have been shown to affect the physiology of various shade plants. ${ }^{5,6)}$

American ginseng has been shown to adapt its metabolism ${ }^{7,8,9)}$ according to light conditions, and the plant's aclimation responses are similare to those observed for Asian ginseng (Panax ginseng C.A. Meyer). ${ }^{10,11,12,13)}$ However, the extent to which American ginseng plants are capable of adapting their photosynthetic pigments, includ- 
ing carotenoid levels, when exposed to high light levels, especially sunflecks, during the initial development of the forest canopy, and then maximize their energy capture once the forest canopy has completed its development has not been studied. Generally, light conditions are more important than a plant's genetic predisposition in determining the pigment content and leaf composition, ${ }^{14)}$ providing an added reason to evaluate American ginseng's tolerance to light conditions found in forest understories. Only a few studies have looked at the physiological acclimation of Asian ginseng to understory light, revealing that plants exposed to light intensities varying from $10 \%$ to $35 \%$ of the solar radiation have higher photosynthetic rates and chlorophyll contents than those exposed to lower (less than $10 \%$ of the solar radiation) and elevated light intensities (above $35 \%$ of the solar radiation). ${ }^{15)}$

Evaluating how American ginseng plants adapt to the changing light levels in the forest understory is essential since the high light levels in the spring have been shown to be critical in whole-plant relative growth of several understory shade-tolerant species as it is a period of rapid accumulation of biomass. ${ }^{16)}$ Sunflecks have also been shown to be essential light sources for various shade-tolerant species, ${ }^{6}$ ) especially when these plants are exposed to sustained high light, below which an acclimation state may not occur. ${ }^{17)}$ However, sunflecks can be sources of excessive light, depending on their duration and periodicity, and can affect the physiology of shade plants ${ }^{5,6)}$ by causing severe photooxydative damage. ${ }^{5,18}$ )

To prevent or at least minimize the possible damages to the chloroplasts when exposed to excessive light levels, higher plants ubiquitously rely on several photoprotective mechanisms, such as the xanthophyll cycle that enables the non-destructive dissipation of excess light absorbed by the chlorophyll pigments, ${ }^{19,20,21,22,23)}$ and changes in chlorophyll concentrations. ${ }^{24)}$ The photoprotective mechanisms present in ginseng plants appear to be limited since previous studies have shown that Asian ginseng plants exposed to prolonged periods of high light levels

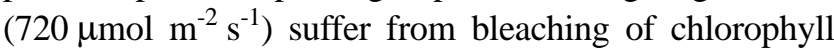
pigments followed by premature leaf death. ${ }^{1,12)}$ Therefore, determining the extent to which American ginseng plants are capable of limiting photooxidative damage to their chloroplasts during the initial development of the forest canopy is key to successfully growing this medicinal plant in forest systems. The objective of this study was to determine the variation in (i) $\mathrm{F}_{\mathrm{v}} / \mathrm{F}_{\mathrm{m}}$, representative of the maximum quantum yield of PSII, and (ii) chlorophyll and carotenoid pigment concentrations in two-year-old Amer- ican ginseng plants in relation to changes in direct, diffuse and total light levels, and sunfleck durations in the understory of a broadleaf forest during a growing season.

\section{MATERIALS AND METHODS}

\section{Plant materials and experimental design}

In October 1998, stratified American ginseng (Panax quinquefolius L.) seeds (Panax Q Farm Ltd, Vernon, BC, Canada) were planted in 15 plots units measuring $6 \mathrm{~m}^{2}$ in a broadleaf forest at l'Île d'Orléans, Québec, Canada (Lat. 46.57 N, Long. 70.56 W). Forest canopy trees were dominated by Fagus grandifolia E., followed by Acer saccharum M. and Betula allenghaniensis B. The location of each plot was allotted randomly on a forest surface area of 1.2 ha. Prior to sowing the ginseng seeds at a density of $30 \mathrm{~kg} \mathrm{ha}^{-1}$, the soil was tilled to a depth of $15 \mathrm{~cm}$ and lime was incorporated into the soil mixture $\left(6 \mathrm{t} \mathrm{ha}^{-1}\right)$ to elevate the soil $\mathrm{pH}$ to an average of 5.2. The plots contained approximately 150 ginseng plants per unit and weeding was done by hand weekly to minimize competition. The average soil mineral concentrations (ppm \pm standard deviation) during the year 2000 were: $20 \pm 3 \mathrm{P}, 96 \pm 11 \mathrm{~K}$, $3673 \pm 451 \mathrm{Ca}, 52 \pm 4 \mathrm{Mg}, 1742 \pm 81 \mathrm{Al}, 268 \pm 13 \mathrm{Fe}$, $2.4 \pm 0.3 \mathrm{Cu}, 11 \pm 3 \mathrm{Mn}, 21 \pm 2 \mathrm{Zn}, 0.2 \pm 0.0 \mathrm{~B}$. The soil had a $12 \%$ organic matter content and an electrical conductivity of $0.121 \pm 0.015 \mathrm{dS} \mathrm{m}^{-1}$.

\section{Statistical analysis}

Statistical analysis was performed using the program named Essential Regression for Excel 97 (ER, 2.219). Using multiple linear regression analysis, the effect of light levels (total (direct+diffuse), direct, and diffuse PFD, and sunfleck duration) and sampling time (15 sampling periods) on $\mathrm{F}_{\mathrm{v}} / \mathrm{F}_{\mathrm{m}}$ and pigment levels was evaluated. Multiple linear regression analysis was also performed to determine the relationship between $\mathrm{F}_{\mathrm{v}} / \mathrm{F}_{\mathrm{m}}$ and pigment levels and dry weight of the shoots and roots of two-yearold American ginseng plants.

\section{Estimation of daily and cumulative light levels and sunfleck durations}

Understory total, direct and diffuse photon flux density (PFD), and sunfleck durations were estimated in each experimental site using hemispherical canopy photography. ${ }^{25)}$ The leaf area index (LAI), an estimation of the area covered by forest canopy leaves, was also measured using hemispherical canopy photography. Due to the heterogeneous nature of the forest canopy, there was no rep- 
etition of light levels, and light conditions were estimated at fixed points (one point per plot) in each plot. Previous studies showed that there are positive correlations between direct sensor measurements and indirect photographic estimates of light transmission with hemispheric photographs. ${ }^{26,27)}$ From May to June 2000, photographs were recorded twice weekly in each plot and at three-week intervals from July to September 2000 (total of 15 times). Hemispherical photographs of the forest canopy were taken skyward on overcast days with uniform cloud cover using a digital camera (CoolPix 800; Nikon Corp., Tokyo, Japan) equipped with a fisheye lens converter (FC-E8; Nikon Corp.) assembled on a Manfrotto leveled tripod one meter above ground level.

The images were analyzed using the imaging software Gap Light Analyzer, version 2.0 (University of Victoria, $\mathrm{BC}$, Canada) which uses a solar radiation model that accounts for the influence of topography and seasonal patterns of cloudiness to estimate light levels. The software estimated mean daily PFD transmitted through the forest canopy during a time period (start and end dates) which, in our case, was from the day after the previous session to the day photographs were recorded. Parameters included in the program are the physical location of the site (geographical location, slope, elevation), solar constant, cloudiness index, beam fraction (ratio of direct to total spectral radiation), and a clear-sky transmission coefficient based on North American conditions. Images were analyzed by transforming image pixel positions into angular coordinates, dividing pixel intensities into sky and non-sky classes (canopy foliage), and computing sky brightness distributions. The estimation of sunfleck durations using hemispherical photography does not take into consideration the movement of canopy leaves by the wind and the effect of clouds. ${ }^{25,28)}$

\section{Air temperature measurements}

From May to September 2000, air temperature was measured using a Data logger (RD-Temp, Omega Technologies Company, Laval, Canada) set at a 12 min recording interval and placed two meters from the ground.

\section{Gingeng leaflet area and maximum quantum yield of PSII measurements}

Using a planimeter (LI-3000A, LI-COR inc., Lincoln, Nebraska, USA), third leaflet area was measured for five samples per experimental unit during each sampling event. Maximum quantum yield of photosystem II, $\mathrm{F}_{\mathrm{v}} / \mathrm{F}_{\mathrm{m}}$ calculated as $\left(\mathrm{F}_{\mathrm{m}}-\mathrm{F}_{\mathrm{o}}\right) / \mathrm{F}_{\mathrm{m}},{ }^{29)}$ was measured on third Amer- ican ginseng leaflets using a Plant Efficiency Analyzer (Hansatech Ltd., Norfolk, UK). From May to June 2000, fluorescence measurements were recorded twice weekly on five samples in each plot and at three-week intervals thereafter. The measurements were made from about 8:30 to 10:00 on 25 min dark adapted leaves. ${ }^{30)}$ The leaves were dark-adapted using leaf clips. A total of 125 measurements of fluorescence were recorded during this study.

\section{Pigment analysis}

$\mathrm{Chl} \mathrm{a,} \mathrm{Chl} \mathrm{b,} \mathrm{V,} \mathrm{A,} \mathrm{Z,} \mathrm{lutein,} \mathrm{neoxanthin} \mathrm{and} \beta$-carotene concentrations were quantified for third leaflets (three samples per plot) collected between 9:00 to 10:00 once weekly from May to beginning of July, and every threeweeks thereafter until September. The leaflets were immediately placed in liquid nitrogen after sampling and then preserved at $-80^{\circ} \mathrm{C}$ until extractions were performed. The three leaflets collected in each plot were pooled and a total of 350 individual analyses were performed during the season. The pigment extraction process was performed in a green illuminated room. Four extractions were performed using a methanol:water $(85: 15 \mathrm{v} / \mathrm{v})$ for the first extraction and pure ice-cold methanol for the three subsequent extractions. The supernatant was stored at $-80^{\circ} \mathrm{C}$ until analysis. A volume of $50 \mu \mathrm{L}$ of the supernatant was injected into a reverse phase HPLC using a Resolve ${ }^{\mathrm{TM}}$ C18 column (Waters, $3.9 \times 300 \mathrm{~mm}, 5 \mu \mathrm{m}$ particle size) connected to Resolve ${ }^{\mathrm{TM}}$ guard-pak inserts. The nature and quantity of each pigment were characterized ${ }^{31)}$ using Z, $\mathrm{Chl} \mathrm{a}$, and $\mathrm{Chl} \mathrm{b}$ as standard pigment preparations obtained from Sigma (St-Louis, Missouri, USA). Spectral information was used to identify pigments $\mathrm{V}$, A, lutein, neoxanthin and $\beta$-carotene.

\section{Dry weight of Shoots and Roots}

In July and September 2000, five American ginseng plants were randomly selected in each experimental unit to measure shoot and root growth. Shoot and root dry weights were determined after a 48-hr drying period at $40^{\circ} \mathrm{C}$. Average values were calculated for each experimental unit and used in statistical analyses.

\section{RESULTS}

\section{Light levels and sunfleck durations}

During the development of the forest canopy in early May, understory total, direct and diffuse PFDs were at their highest levels of the season and dramatically decreased by 
over $61 \%$ following canopy development (Fig. 1). Similarly, sunfleck durations in the understory decreased by $76 \%$ following the development of the forest canopy (Fig. 1), after which the light PFDs and sunfleck durations stabilized and remained at mean values of less than $10 \mathrm{~mol}$ $\mathrm{m}^{-2} \mathrm{~d}^{-1}$ and $2 \mathrm{~h} \mathrm{~d}^{-1}$, respectively.

\section{Leaf area of forest canopy and ginseng leaves}

The leaf area index (LAI) of forest canopy leaves quadrupled in the span of a week (from mid-May to end of May) with little variation thereafter (Fig. 2A), whereas leaflet area of two-year-old American ginseng plants increased gradually from a low of $4.6 \mathrm{~cm}^{2}$ in mid-May to $34.5 \mathrm{~cm}^{2}$ in July and stabilized thereafter (Fig. 2B). Twoyear-old American ginseng plants developed from midMay to June, and they were mature in July (Fig. 2B).

\section{Air temperature}

In the experimental site, air temperature was at its lowest in mid-May with day and night temperatures of $14^{\circ} \mathrm{C}$ and $7^{\circ} \mathrm{C}$, respectively (Fig. 3). Air temperatures in the forest understory gradually increased to reach day temperatures of $20^{\circ} \mathrm{C}$ in July (Fig. 3). After July, air temperatures in the forest understory gradually decreased (Fig. 3).

\section{Fluorescence}

In mid-May, developing American ginseng plants expressed the second lowest average $\mathrm{F}_{\mathrm{v}} / \mathrm{F}_{\mathrm{m}}$ of the growing season with 0.70 (Fig. 4A). By the end of May, $F_{v} / F_{m}$ of ginseng plants increased by over $11 \%$ to an average of 0.78 , and further increased to 0.79 during the month of June (Fig. 4A). Both diffuse PFD and sampling time affected $\mathrm{F}_{\mathrm{v}} / \mathrm{F}_{\mathrm{m}}$ during the development of American ginseng plants (Table 1) where the $\mathrm{F}_{\mathrm{v}} / \mathrm{F}_{\mathrm{m}}$ of two-year-old

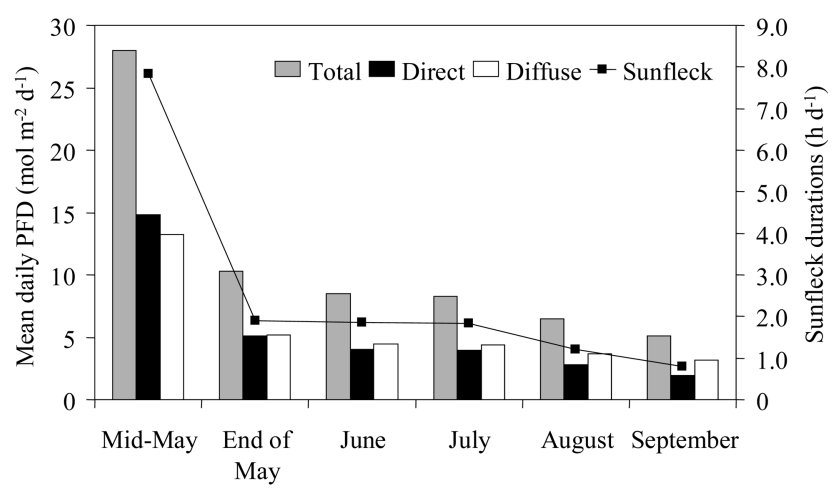

Fig. 1. Seasonal variation in the mean daily understory total, direct and diffuse photon flux density (PFD), and sunfleck durations from mid-May to September 2000. developing plants from mid-May to June was negatively linearly correlated with daily diffuse PFD and positively linearly correlated with sampling time, accounting for $59 \%$ of the variation (Table 1). As the season progressed, $\mathrm{F}_{\mathrm{v}} / \mathrm{F}_{\mathrm{m}}$ gradually increased to reach an average value of 0.81 during the month of August (Fig. 4A). In mature plants, $\mathrm{F}_{\mathrm{v}} / \mathrm{F}_{\mathrm{m}}$ was best predicted by daily total PFD, accounting for $21 \%$ of the variation (Table 1) where
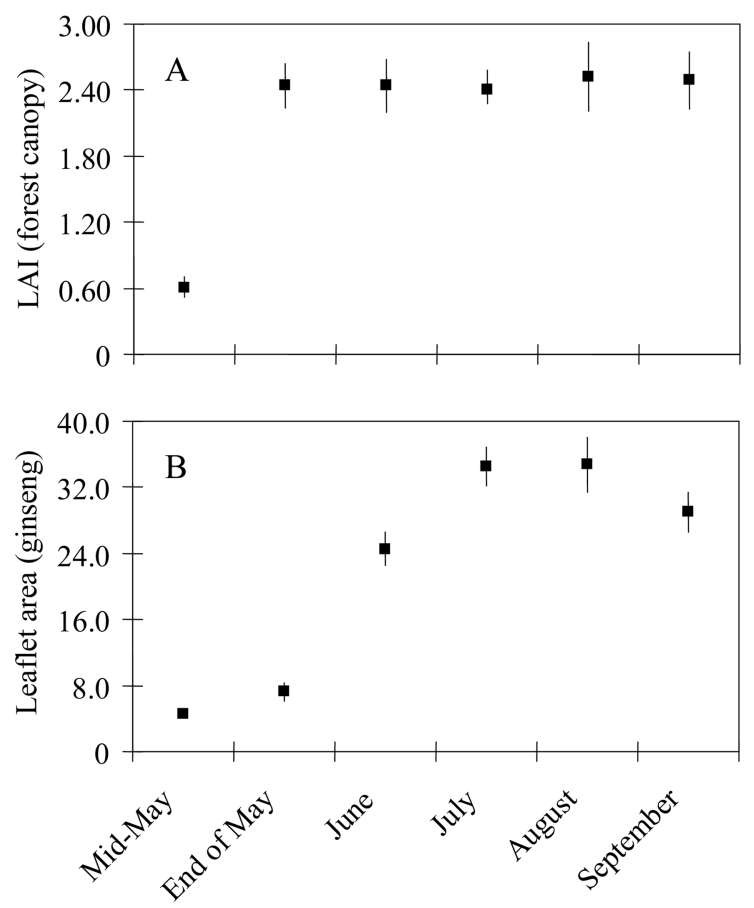

Fig. 2. Seasonal variation in the mean leaf area index (LAI) of forest canopy leaves (A) and leaflet area of two-year-old American ginseng (B) from mid-May to September 2000.

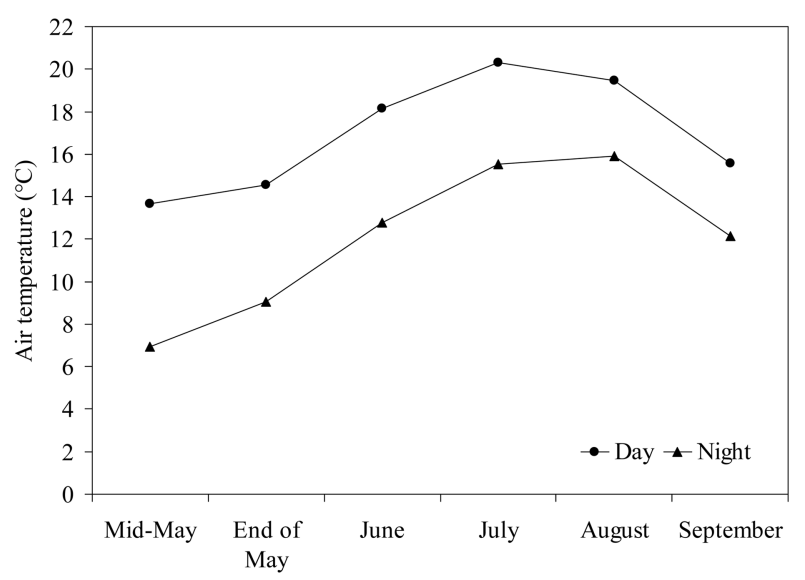

Fig. 3. Seasonal variation in the mean day and night air temperatures in the understory of a broadleaf forest from mid-May to September 2000. 
Table 1. Relationship between mean daily understory PFD and sampling time, and $\mathrm{F}_{\mathrm{v}} / \mathrm{F}_{\mathrm{m}}$ and photosynthetic pigments of two-year-old American ginseng plants collected in a broadleaf forest. NS, **: non-significant and significant at $P \leq 0.01$

\begin{tabular}{|c|c|c|c|c|c|c|}
\hline \multirow{2}{*}{ Parameter } & \multicolumn{3}{|c|}{ Developing plants (mid-May to June) } & \multicolumn{3}{|c|}{ Mature plants (July to August) } \\
\hline & Best model & Equation & $\mathrm{R}^{2}$ & Best model & Equation & $\mathrm{R}^{2}$ \\
\hline $\mathrm{F}_{\mathrm{v}} / \mathrm{F}_{\mathrm{m}}$ & $\begin{array}{l}\text { Diffuse PFD(1) } \\
\& \text { sampling time(2) }\end{array}$ & $\begin{aligned} \mathrm{y}= & 0.81-0.00854(1) \\
& +0.0022(2)\end{aligned}$ & $0.59 * *$ & Total PFD & $\mathrm{y}=0.842-0.0051 \quad(\mathrm{x})$ & $0.21 * *$ \\
\hline EPS & Diffuse light & $\mathrm{y}=1.081-0.0292(\mathrm{x})$ & $0.62 * *$ & None & - & NS \\
\hline Chl a+b & None & - & NS & None & - & NS \\
\hline $\mathrm{Chl} \mathrm{a/b}$ & Direct PFD & $\mathrm{y}=4.57+0.0416(\mathrm{x})$ & $0.20 * *$ & None & - & NS \\
\hline $\mathrm{VAZ/Chl} \mathrm{a+b}$ & $\begin{array}{l}\text { Sampling time(1) } \\
\& \text { diffuse PFD(2) }\end{array}$ & $\begin{aligned} \mathrm{y}= & 1.317-0.152(1) \\
& +0.00262(2)\end{aligned}$ & $0.48 * *$ & None & - & NS \\
\hline VAZ/Total Car & None & - & NS & Diffuse PFD & $\mathrm{y}=0.482+0.04091(\mathrm{x})$ & $0.30 * *$ \\
\hline
\end{tabular}

mature plants exposed to higher daily total PFD had lower $\mathrm{F}_{\mathrm{v}} / \mathrm{F}_{\mathrm{m}}$ than those exposed to lower daily total PFD, even when the total PFD changes were generally low (5.1 to $8.3 \mathrm{~mol} \mathrm{~m}^{-2} \mathrm{~d}^{-1}$ ) (Fig. 1). In September, there was a sudden drop in $\mathrm{F}_{\mathrm{v}} / \mathrm{F}_{\mathrm{m}}$ to an average of 0.68 (Fig. 4A) at which time, a general yellowing of the leaves in the experimental site was noted.

\section{Epoxidation state of the xanthophyll cycle (EPS)}

The EPS in two-year-old American ginseng plants was at its lowest value in mid-May (0.63) (Fig. 4B) when American ginseng plants were exposed to the highest PFDs of the season (Fig. 1). From mid-May to end of May, EPS increased by $44 \%$ followed by its stabilization thereafter (Fig. 4B). EPS levels in developing American ginseng plants were negatively linearly correlated with daily diffuse PFD, accounting for $62 \%$ of the variation (Table 1). In contrast, EPS levels in mature plants (July to August) were not correlated with light PFD or sampling time (Table 1).

\section{Chl a+b, Chl a/b, VAZ/Chl a+b, VAZ/Total Car}

Chl a+b (Fig. 5A) and Chla/b (Fig. 5B) in two-year-old American ginseng plants gradually decreased during the growing season, where the highest levels were measured in mid-May. The $\mathrm{Chl} \mathrm{a}+\mathrm{b}$ ratio in developing and mature American ginseng plants was not correlated with light PFD or sampling time (Table 1). While the $\mathrm{Chl} \mathrm{a} / \mathrm{b}$ ratio in developing American ginseng plants was positively linearly correlated with direct PFD accounting for $20 \%$ of the variation, $\mathrm{Chl} \mathrm{a} / \mathrm{b}$ was not correlated with light $\mathrm{PFD}$ in mature plants (Table 1).

Ginseng plants exposed to the highest light levels of the season (mid-May) had 9\% lower VAZ/Chl a+b than plants at the end of May, and in June, the ratio decreased to levels well below those measured in mid-May (Fig. 6A). Diffuse
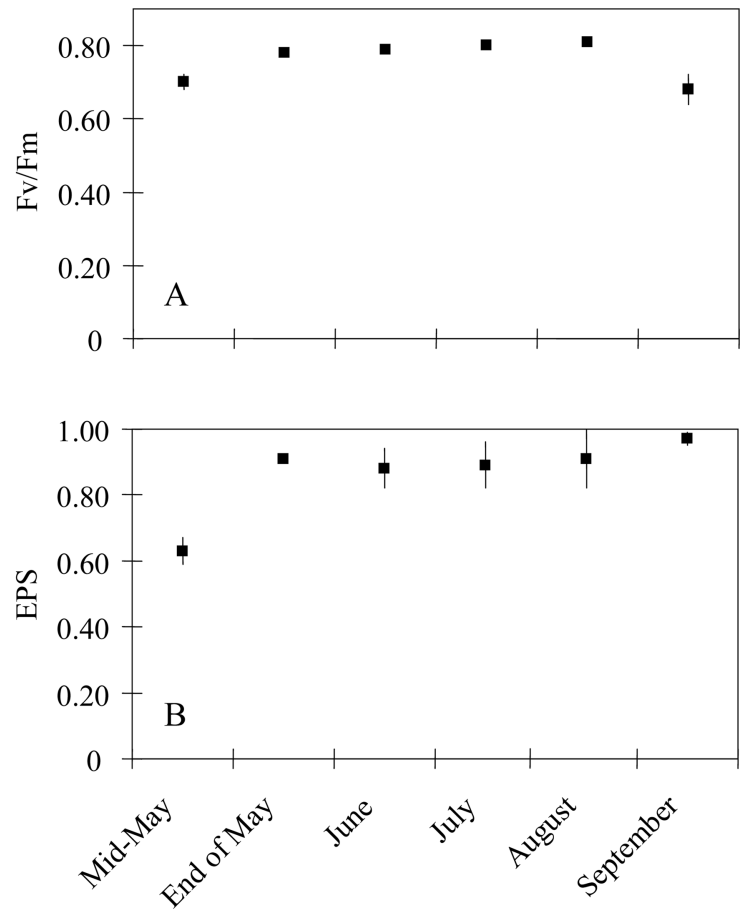

Fig. 4. Seasonal variation in the mean $\mathrm{F}_{v} / \mathrm{F}_{\mathrm{m}}(\mathrm{A})$ and $\mathrm{EPS}(\mathrm{B})$ of two-year-old American ginseng plants cultivated in a broadleaf forest.

PFD and sampling time were correlated with VAZ/Chl a+b ratio in developing American ginseng plants, accounting for $48 \%$ of the variation (Table 1). The VAZ/Chl $\mathrm{a}+\mathrm{b}$ ratio was not correlated with light PFD or the duration of sunflecks in mature American ginseng plants (Table 1) with averages ranging from 1.23 to 1.29 (Fig. 6A). During the growing season, VAZ/Total Car in two-year-old American ginseng plants consistently decreased until the end of the growing season (Fig. 6B). While VAZ/Total Car was not correlated with light PFD or sunfleck durations in developing American ginseng plants, this ratio was positively 
linearly related to diffuse PFD in mature plants, accounting for $30 \%$ of the variation (Table 1).
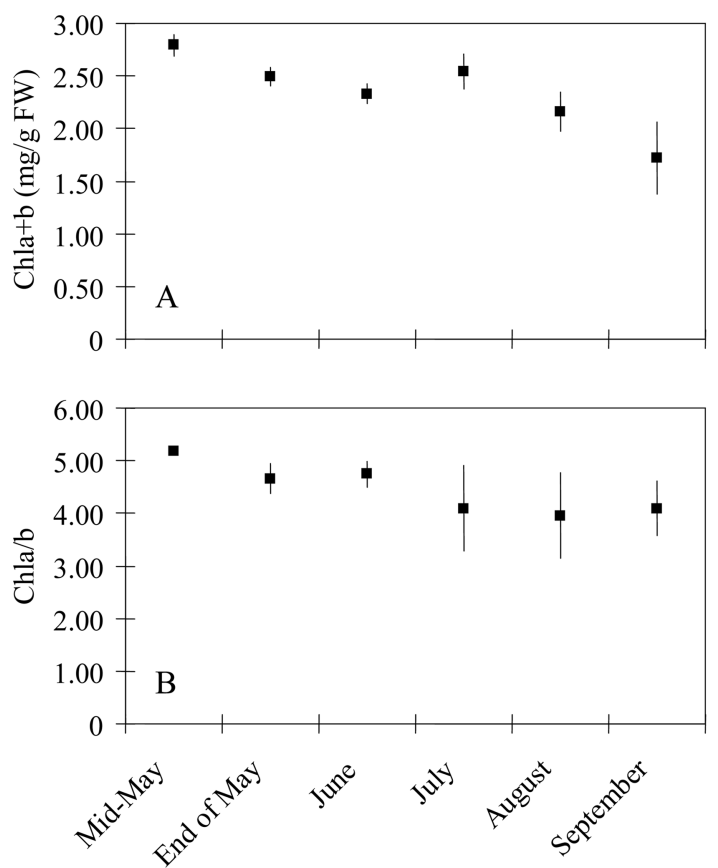

Fig. 5. Seasonal variation in the mean $\mathrm{Chl} a+b(\mathrm{~A})$ and $\mathrm{Chl} a / b$ (B) in two-year-old American ginseng plants cultivated in a broadleaf forest.
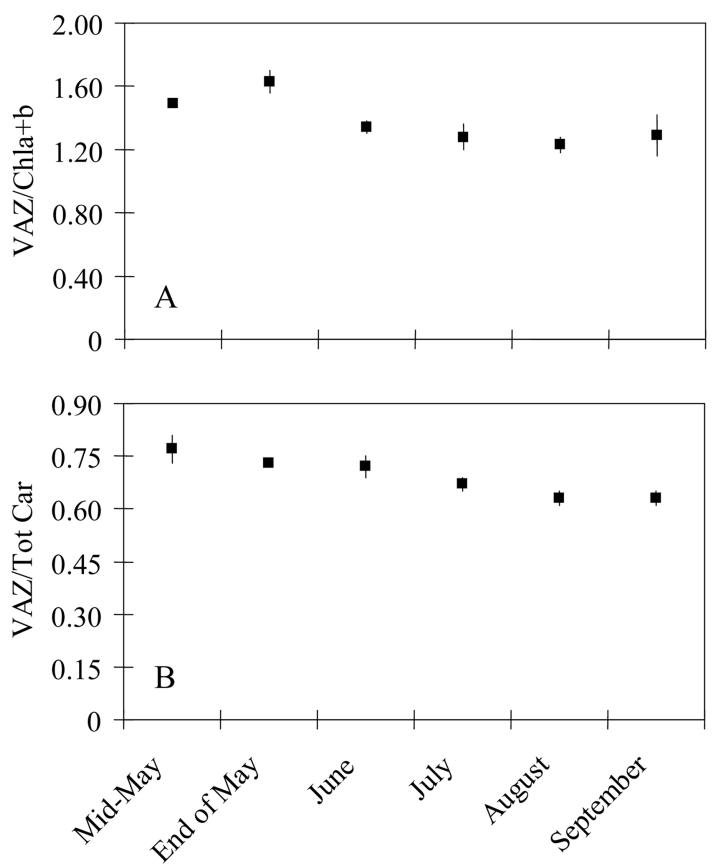

Fig. 6. Seasonal variation in the mean VAZ/Chl $a+b(A)$ and VAZ/Total Car (B) in two-year-old American ginseng plants cultivated in a broadleaf forest.
7. Relationship between $\mathbf{F}_{v} / \mathbf{F}_{m}$ and root and shoot dry weight, and pigment contents

Although no significant relationship was found for root DW (data not shown), the shoot DW of two-year-old American ginseng plants collected in July 2000 was negatively linearly related to $F_{v} / F_{m}$ (Fig. 7). The $F_{v} / F_{m}$ measured in two-year-old American ginseng plants was positively linearly related to the interaction between EPS, VAZ/Chl a/b, Chl a/b and VAZ/Total Car during the development of American ginseng plants (May to June) (Fig. $8 \mathrm{~A}$ ), accounting for up to $64 \%$ of the variation. The $\mathrm{F}_{\mathrm{v}} / \mathrm{F}_{\mathrm{m}}$ was also positively linearly related to EPS from July to

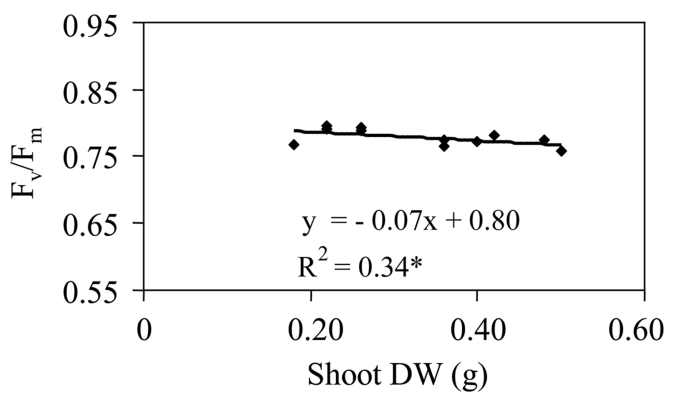

Fig. 7. Relationship between mean $\mathrm{F}_{\mathrm{v}} / \mathrm{F}_{\mathrm{m}}$ (May to July 2000) and shoot dry weight (DW) of two-year-old American ginseng in July 2000 in a broadleaf forest. *: significant at $P \leq 0.05$.
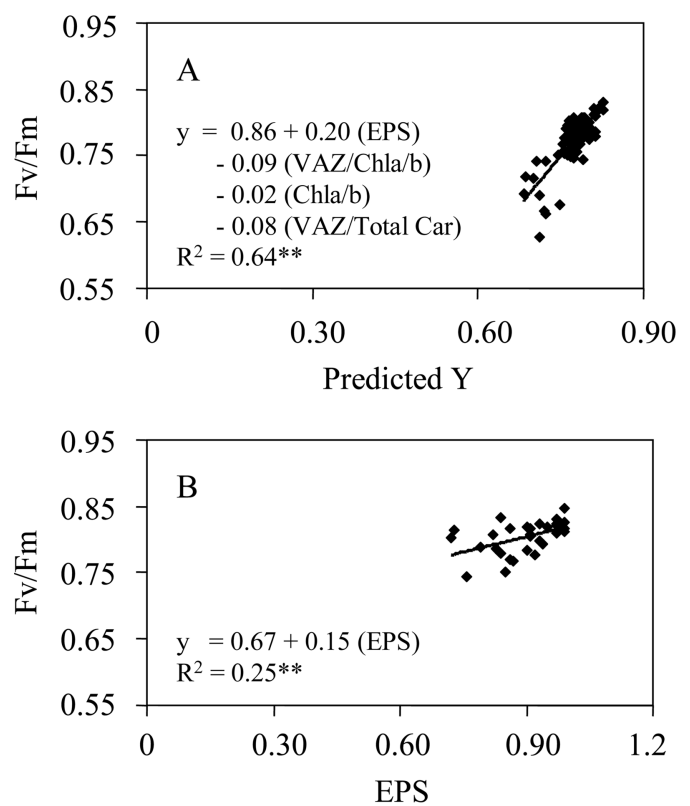

Fig. 8. Relationship between mean $\mathrm{F}_{\mathrm{v}} / \mathrm{F}_{\mathrm{m}}$, and Chlorophyll (Chl) and carotenoid (Car) ratios in developing (May to June 2000) (A) and mature (July to August 2000) (B) twoyear-old American ginseng plants cultivated in a broadleaf forest. $* *$ : significant at $P \leq 0.01$. 
August, accounting for $25 \%$ of the variation (Fig. 8B).

\section{DISCUSSION}

Our results suggest that leaf-level acclimation is a strategy used by forest-grown American ginseng to capitalize on the short periods of high PFDs and long sunfleck durations during the initial development of the forest canopy while minimizing negative carbon balance during the summer months of shade and shorter sunfleck durations. Exposed to the highest total PFDs of the season, averaging $28 \mathrm{~mol} \mathrm{~m}^{-2} \mathrm{~d}^{-1}$ or $365 \mu \mathrm{mol} \mathrm{m} \mathrm{s}^{-2}$ (Fig. 1), young ginseng plants expressed an average maximum quantum yield of PSII of 0.70 (Fig. 4A), which is among the lowest measurements of the season and indicative of photoinhibition. Our results are concordant with Parmenter and Littlejohn $(1998)^{11)}$ for Asian ginseng plants grown under artificial shade, and could indicate the presence of important fluorescence quenching mechanisms. ${ }^{19,20,32)}$ In midMay, the lowest EPS of the season was recorded (Fig. $4 \mathrm{~B}$ ), indicating a greater investment in $\mathrm{Z}$ and $\mathrm{A}$ in the leaves to evacuate excess light energy that could cause damages to the photosynthetic apparatus. The xanthophylls, especially $Z$, are essential elements that evacuate excess light energy absorbed by plants and these pigments can contribute to the elimination of over $75 \%$ of absorbed photons as heat. ${ }^{20)}$ The low air temperatures, below $15^{\circ} \mathrm{C}$ (Fig. 3), in May could have significantly contributed to stunting $\mathrm{F}_{\mathrm{v}} / \mathrm{F}_{\mathrm{m}}$ of American ginseng plants at the beginning of the growing season since our results showed that sampling time significantly influenced $\mathrm{F}_{\mathrm{v}} / \mathrm{F}_{\mathrm{m}}$ (Table 1). Previous studies have shown that American ginseng plants exposed to air temperatures of less than $25^{\circ} \mathrm{C}$ have rapidly declining photosynthetic rates. ${ }^{7,33)}$ However, the added effect of the low temperatures (Fig. 3) with high light levels (Fig. 1) during the initial deployment of the canopy did not induce permanent photodamage to the photosynthetic apparatus, as shown by the reestablishment of high $F_{v} / F_{m}$ thereafter (Fig. 4A).

Similar to higher plants,${ }^{17)}$ our results showed that the $\mathrm{Chl} \mathrm{a} / \mathrm{b}$ ratio in developing American ginseng plants was largely influenced by direct PFD (Table 1). In mid-May, the $\mathrm{Chl} \mathrm{a} / \mathrm{b}$ in developing ginseng plants was higher than 5 (Fig. 5A), showing a high investment in Chl a-binding core antenna proteins relative to $\mathrm{Chl} \mathrm{a} / \mathrm{b}$ bonding lightharvesting complexes ${ }^{34)}$ to minimize the absorption of excess light. In mid-May and June, the Chla/b ratio and xanthophyll pigment content (Fig. 8A) were significantly correlated with $\mathrm{Fv} / \mathrm{Fm}$, accounting for up to $64 \%$ of the variation, when the highest light levels of the season were recorded. However, our results did not show a significant correlation between $\mathrm{Fv} / \mathrm{Fm}$ and $\mathrm{Chl} \mathrm{a}+\mathrm{b}$ probably because $\mathrm{Chl}$ content does not necessarily dictate the actual potential for photon capture. ${ }^{35)}$ An increase in VAZ/Chl a+b (Fig. 5B) in the leaves of developing American ginseng plants was observed, which could have acted as a defense mechanism by reducing the formation of reactive oxygen during severe chilling, ${ }^{36)}$ especially during the early development of the plants when they were exposed to air temperatures averaging $7^{\circ} \mathrm{C}$.

Although photoinhibition occurred when American ginseng was exposed to long sunflecks and elevated PFDs during initial forest canopy development, plants benefited from these elevated light PFDs with increased carbon gains. Our results showed that plants exposed to the highest light levels and longest sunflecks from mid-May to July had increased shoot weight gains (Fig. 7). These results are concordant with Sims and Pearcy $(1993)^{37)}$ which showed that the carbon gain of an understory plant exposed to sunfleck regimes was $26 \%$ to $60 \%$ of those grown under diffuse light. After full closure of the forest canopy (July to September), there was no significant relationship between plant growth and light, presumably because the PFDs and sunfleck durations were severely low in the forest understory, with values below $5 \mathrm{~mol} \mathrm{~m}^{-2}$ $\mathrm{d}^{-1}$ and $1 \mathrm{~h} \mathrm{~d}^{-1}$, respectively, which are well below optimal light levels for ginseng growth. ${ }^{15)}$

The fluorescence quenching mechanisms used by ginseng plants to dissipate the excess PFD was sufficiently rapid to prevent any permanent or long-term pigment degradation since the $\mathrm{F}_{\mathrm{v}} / \mathrm{F}_{\mathrm{m}}$ increased by over $10 \%$ in the span of less than a week (from May 20 to 26) following the development of the forest canopy (Fig. 4A). Our results are in accordance with previous studies which reported that Asian ginseng plants transferred from 630 to $250 \mathrm{mmol} \mathrm{m}^{-2} \mathrm{~s}^{-1}$ or $120 \mathrm{mmol} \mathrm{m}^{-2} \mathrm{~s}^{-1}$ express a $7 \%$ increase in $F_{v} / F_{m}$ (from 0.70 to 0.75 ) in only 4 days. ${ }^{11)}$ Proteins instrumental in energy metabolism, protein stabilization and protection against oxidative stress could have been abundant in American ginseng plants following exposure to high PFDs, as previously shown in Asian ginseng exposed to $1700 \mathrm{mmol} \mathrm{m}^{-2} \mathrm{~s}^{-1}$ for up to 4 hours. ${ }^{13)}$

While American ginseng plants were exposed to high light levels during the initial deployment of the forest canopy, they were exposed to less than optimal light levels (less than $10.3 \mathrm{~mol} \mathrm{~m}^{-2} \mathrm{~d}^{-1}$ or $188 \mu \mathrm{mol} \mathrm{m} \mathrm{s}^{-2}$ total PFD) after the full development of the forest canopy and until the end of the growing season (Fig. 1). The elevated $F_{v} / F_{m}$ 
measured in July and August (Fig. 4A) suggest that mature two-year-old American ginseng plants were not only exempt from light stress, but also from temperature and other stresses, which have been shown to influence $\mathrm{F}_{\mathrm{v}} / \mathrm{F}_{\mathrm{m} .}{ }^{38,39)}$ Our results showed that average day air temperatures in the forest understory during July and August did not exceed $20^{\circ} \mathrm{C}$ (Fig. 3), which is within an acceptable level for optimal photosynthetic rates of ginseng plants. ${ }^{7,33)}$ When American ginseng plants were exposed to sunflecks after full closure of the forest canopy, the EPS was the preferred mechanism to evacuate any excess light energy, accounting for $25 \%$ of the variation in $\mathrm{Fv} /$ Fm (Fig. 8B). However, although American ginseng is a shade plant and therefore shade loving, the relative electron transport rate and carbon fixation rate were probably well below that of light saturation when exposed to the low light PFDs (less than $188 \mu \mathrm{mol} \mathrm{m} \mathrm{m}^{-2} \mathrm{~s}^{-1}$ ) after forest canopy development, as previously shown in Asian ginseng plants. ${ }^{12,40,41)}$ At the end of the growing season (September), our results indicated that senescence had begun because the ginseng plants showed signs of leaf chlorosis. At this time, $\mathrm{F}_{\mathrm{v}} / \mathrm{F}_{\mathrm{m}}$ had decreased by $17 \%$ (Fig. 4A) with an associated $20 \%$ drop in total Chl concentration (Fig. 5A). Our results are concordant with the fact that $\mathrm{Chl}$ degradation and decreases in $\mathrm{F}_{\mathrm{v}} / \mathrm{F}_{\mathrm{m}}$ are closely observed during leaf senescence. ${ }^{42)}$

Forest-grown American ginseng plants acclimate to understory light conditions by changing from energy dissipation of absorbed photons during the initial deployment of the forest canopy to light limitation after the deployment of the forest canopy. Our results showed that daily and seasonal light changes significantly influenced the photosynthetic utilization, as shown by the variations in $\mathrm{F}_{\mathrm{v}} / \mathrm{F}_{\mathrm{m}}$, and the photosynthetic pigment composition of two-year-old American ginseng plants, especially in midMay when the light levels were the highest $\left(28 \mathrm{~mol} \mathrm{~m}^{-}\right.$ $\left.2 \mathrm{~d}^{-1}\right)$. The low $\mathrm{F}_{\mathrm{v}} / \mathrm{F}_{\mathrm{m}}$, depressed EPS levels and elevated VAZ/Total Car observed in developing American ginseng plants during the initial deployment of the forest canopy suggests that there was an active dissipation of excess light energy as heat absorbed by the chlorophyll pigments. As light PFDs decreased after the deployment of the forest canopy to less than $10 \mathrm{~mol} \mathrm{~m}^{-2} \mathrm{~d}^{-1}, \mathrm{Chl} \mathrm{a} / \mathrm{b}$ also decreased suggesting that the plants were increasingly investing in light harvesting pigments versus reaction centers in order to absorb the fleeting light energy. Further research is necessary to determine how developing versus mature American ginseng plants grown in a forest understory are influenced by higher PFDs than those tested in this study (i.e. greater than $28 \mathrm{~mol} \mathrm{~m}^{-2} \mathrm{~d}^{-1}$ ), and at which PFD chlorosis and irreversible photoinhibition would be observed.

\section{ACKNOWLEDGEMENTS}

The authors wish to express their gratitude to Les Fraises de l'île d'Orléans, Agriculture and Agri-Food Canada and the Horticultural Research Center for their financial support. We would also like to thank Claudine Ménard, Daniel Mailly, and Guy Samson for their technical support.

\section{REFERENCES}

1. Proctor, J. T. A. and Bailey, W. G. : Ginseng: industry, botany and culture. Hortic-Revue. 9, 187-236 (1987).

2. Anderson, R. C., Fralish, J. S., Armstrong, J. E. and Benjamin, P. K. : The ecology and biology of Panax quinquefolium L. (Araliaceae) in Illinois. Am. Midl. Nat. 129, 357-372 (1993).

3. Briskin, D. P. : Medicinal plants and phytomedicines: linking plant biochemistry and physiology to human health. Plant Physiol. 124, 507-514 (2000).

4. Hsu, P. C. : Commercial production of American ginseng (Panax quinquefolius L.). Native Plants J. 3, 106-108 (2002).

5. Königer, M., Harris, G. C., Virgo, A. and Winter, K. : Xanthophyll-cycle pigments and photosynthetic capacity in tropical forest species: a comparative field study on canopy, gap and understory plants. Oecol. 104, 280-290 (1995).

6. Kursar, T. A. and Coley, P. D. : Contrasting modes of light acclimation in two species of the rainforest understory. Oecol. 121, 489-498 (1999).

7. Lee, S. S., Proctor, J. T. A. and Choi, K. T. : Influence of monochromatic light on photosynthesis and leaf bleaching in Panax species. J. Ginseng Res. 23, 1-7 (1999).

8. Miskell, J.-A., Parmenter, G. and Eaton-Rye, J. J. : Decreased hill reaction rates and slow turnover of transitory starch in the obligate shade plant Panax quinquefolius L. (American ginseng ). Planta 215, 969-979 (2002).

9. Li, W., Wan, Z. and Yang, S. : Effects of different light transmission rate on American ginseng's photosynthesis. Ying Yong Sheng Tai Xue Bao 15, 261-264 (2004).

10. Zhang, Z. A., Xu, K. Z., Quiao, C. G., Yin, Y. Y., Chen, X. and Quiao, R. T. : The effects of light on the microstructure and ultrastructure of Panax ginseng leaves. p. 504-509. In: Bailey, W.G., Whitehead, C., Proctor, J.T.A. and Kyle, J.T. (eds), The Challenges of the $21^{\text {st }}$ Century. Proceeding of the International Ginseng Conference. Simon Fraser University, Burnaby, BC (1995).

11. Parmenter, G. and Littlejohn, R. : The effect of irradiance 
during leaf development on photoinhibition in Panax ginseng C.A. Meyer. J. Ginseng Res. 22, 102-113 (1998).

12. Parmenter, G. and Littlejohn, R. : Effect of shade on growth and photosynthesis of Panax ginseng. N.Z.J. Crop Hort. Sci. 28, 255-269 (2000).

13. Nam, M. H., Heo, E. J., Kim, J. Y., Kim, S. I., Kwon, K.-H., Seo, J. B., Kwon, O., Yoo, J. S. and Park, Y. M. : Proteome analysis of the responses of Panax ginseng C.A. Meyer leaves to high light: Use of electrospray ionization quadrupole-time of flight mass spectrometry and expressed sequence tag data. Proteomics 3, 2351-2367 (2003).

14. Rosevear, M. J., Young, A. J. and Johnson, G. N. : Growth conditions are more important than species origin in determining leaf pigment content of British plant species. Funct. Ecol. 15, 474-480 (2001).

15. Wang, H., Fan, J., Yang, X., Fan, G., Liou, Q. and Dai, H. : A study on ginseng cultivation under forest conditions and its physiological and ecological characteristics. p. 452-462. In: Bailey, W.G., Whitehead, C., Proctor, J.T.A. and Kyle, J.T. (eds), The Challenges of the $21^{\text {st }}$ Century. Proceeding of the International Ginseng Conference. Simon Fraser University, Burnaby, BC (1995).

16. Rothstein, D. E. and Zak, D. R. : Photosynthetic adaptation and acclimation to exploit seasonal periods of direct irradiance in three temperate, deciduous-forest herbs. Funct. Ecol. 15, $722-731$ (2001).

17. Yin, Z. H. and Johnson, G. N. : Photosynthetic acclimation of higher plants to growth in fluctuating light environments. Photosynth. Res. 63, 97-107 (2000).

18. Pearcy, R. W. : Photosynthetic response to sunflecks and light gaps: mechanisms and constraints. p. 255-271. In: Baker, N.R. and Bowyer, J.R. (eds), Photoinhibition of Photosynthesis from Molecular Mechanisms to the Field. BIOS Scientific Publishers Limited, Oxford, UK (1994).

19. Demmig-Adams, B., Gilmore, A. M. and Adams III, W. W. : Carotenoids 3: in vivo functions of carotenoids in higher plants. FASEB J. 10, 403-412 (1996a).

20. Demmig-Adams, B., Adams III, W. W., Barker, D. H., Logan, B. A., Bowling, D.R. and Verhoeven, A.S.: Using chlorophyll fluorescence to assess the fraction of absorbed light allocated to thermal dissipation of excess excitation. Physiol. Plant 98, 253-264 (1996b).

21. Niinemets, Ü., Bilger, W., Kull, O. and Tenhunen, J. D. : Acclimation to high irradiance in temperate deciduous trees in the field: changes in xanthophyll cycle pool size and in photosynthetic capacity along a canopy gradient. Plant Cell Environ. 21, 1205-1218 (1998).

22. Havaux, M. and Niyogi, K. : The violaxanthin cycle protects plants from photooxidative damage by more than one mechanism. Proc. Natl. Acad. Sci. USA 96, $8762-8767$ (1999).

23. Li, X.-P., Bjorkman, O., Shih, C., Grossman, A. R., Rosen- quist, M., Jansson, S. and Niyogi, K. K. : A pigment-binding protein essential for regulation of photosynthetic light harvesting. Nature 403, 391-395 (2000).

24. Chow, W. S., Anderson, J. M. and Melis, A. : The photosystem stoichiometry in thylakoids of some Australian shadeadapted plant species. Aust. J. Plant Physiol. 17, 665-674 (1990).

25. Beaudet, M. and Messier, C. : Variation in canopy openness and light transmission following selection cutting in northern hardwood stands: an assessment based on hemispherical photographs. Agricult. Forest Meterol. 110, 217-228 (2002).

26. Easter, M. J. and Spies, T. A. : Using hemispherical photography for estimating photosynthetic photon flux density under canopies and in gaps in Douglas-fir forests of the Pacific Northwest. Can. J. Forest Res. 24, 2050-2058 (1994).

27. Gendron, F., Messier, C. and Comeau, P. G. : Comparison of various methods for estimating the mean growing season percent photosynthetic photon flux density in forests. Agricult. Forest Meterol. 92, 55-70 (1998).

28. Canham, C. D., Denslow, J. S., Platt, W. J., Runkle, J. R., Spies, T. A. and White, P. S. : Light regimes beneath closed canopies and tree-fall gaps in temperate and tropical forests. Can. J. Forest Res. 20, 620-631 (1990).

29. Maxwell, K. and Johnson, G. N. : Chlorophyll fluorescence a practical guide. J. Exp. Bot. 51, 659-668 (2000).

30. Krause, G. H. and Weis, E. : Chlorophyll fluorescence and photosynthesis: the basics. Annu. Rev. Plant Physiol. Plant Mol. Biol. 42, 313-349 (1991).

31. Gilmore, A. M. and Yamamoto, H. Y. : Resolution of lutein and zeaxanthin using non-endcapped, lightly carbon-loaded $\mathrm{C}_{18}$ high-performance liquid chromatographic column. $J$. Chromatogr. 543, 137-145 (1991).

32. Demmig-Adams, B. and Adams III, W. W. : Photoprotection and other responses of plants to high light stress. Annu. Rev. Plant Physiol. Plant Mol. Biol. 43, 599-626 (1992).

33. Xu, S. X., Wang, H. Y. and Chen, Y. J. : Studies on chemistry of Panax ginseng and Panax quinquefolius in China. p. 487489. In: Bailey, W.G., Whitehead, C., Proctor, J.T.A. and Kyle, J.T. (eds), The Challenges of the $21^{\text {st }}$ Century. Proceeding of the International Ginseng Conference. Simon Fraser University, Burnaby, BC (1995).

34. Johnson, G. N., Rumsey, F. J., Headley, A. D. and Sheffield, E. : Adaptations to extreme low light in the fern Trichomanes speciosum. New Phytology 148, 423-431 (2000).

35. Manetas, Y., Drinia, A. and Petropoulou, Y. : High contents of anthocyanins in young leaves are correlated with low pools of xanthophyll cycle components and low risk of photoinhibition. Photosynthetica 40, 349-354 (2002).

36. Liu, P., Meng, Q.-W., Zou, Q., Zhao, S.-J. and Liu, Q.-Z. : Effects of cold-hardening on chilling-induced photoinhibition of photosynthesis and on xanthophyll cycle pigments in 
sweet pepper. Photosynthetica 39, 467-472 (2001).

37. Sims, D. A. and Pearcy, R. W. : Sunfleck frequency and duration affects growth rate of the understorey plant, Alocasia macrorrhiza. Funct. Ecol. 7, 683-689 (1993).

38. Hüner, N. P. A., Öquist, G., Hurry, V. M., Krol, M., Falk, S. and Griffith, M. : Photosynthesis, photoinhibition and low temperature acclimation in cold tolerant plants. Photosynth. Res. 37, 19-39 (1993).

39. Leipner, J., Fracheboud, Y. and Stamp, P. : Acclimation by suboptimal growth temperature diminishes photooxidative damage in maize leaves. Plant Cell Environ. 20, 366-372 (1997).
40. Jo, J. S. and Won, J. Y. : Studies on the photosynthesis of Korean ginseng. Korean J. Crop Sci. 29, 89-97 (1984).

41. Jo, J. S., Won, J. Y. and Mok, S. K. : Studies on the photosynthesis of Korean ginseng iii. Effects of light transparent rate of shading on the photosynthesis ability of Korean ginseng plant (Panax ginseng C.A. Meyer). Korean J. Crop Sci. 31, 408-415 (1986).

42. Humbeck, K., Quast, S. and Krupinska, K. : Functional and molecular changes in the photosynthetic apparatus during senescence of flag leaves from field-grown barley plants. Plant Cell Environ. 19, 337-344 (1996). 